(2021), 4 (1): 23-28

\title{
UTILIZING WHATSAPP GROUP AS A SUPPORTING MEDIUM IN ENGLISH COURSE E-LEARNING: STUDENTS' PERSPECTIVES
}

\author{
Tutut Nani Prihatmi \\ National Institute of Technology Malang \\ tutut.nani@lecturer.itn.ac.id
}

\begin{abstract}
This study investigates the students' perception of using WhatsApp Group as a supporting medium in English Course e-learning. The overall learning course was using a web-based LMS named SPADA ITN Malang and partially using Google Meet. This study's research design is survey research with the help of online questionnaires on Google Form. The respondents were fifty students of the Informatics Engineering department at the National Institute of Technology Malang. The research findings showed that the students had high positive perceptions toward the English course WA group regarding ease-of-use, usefulness, and communication. This study suggests that the WA group's utilization in every course is essential to help students gain more understanding of the materials delivered on SPADA and bridge the lecturer-students communication gap during the e-learning process.
\end{abstract}

Keywords: WhatsApp group, e-learning supporting media, students’ perspectives

CPendidikan Bahasa Inggris FPISH IKIP BU Malang

\section{Introduction}

Rapid advances in digital technology and social media have also created new opportunities for integrating the two in learning strategies. While claimed to cause the decrease in student learning achievement, social media includes messaging applications, have been widely used as instructional media in higher education and show a trend towards positive results (Prihatmi, 2018). The role of messaging applications becomes high in e-learning, especially during the COVID-19 pandemic outbreak, requiring all educational institutions to go online. One of the primary applications used during elearning in Indonesia is WhatsApp Messenger, widely known as WA.

With 2 billion users in the year 2020, WhatsApp is the most popular instant messaging application worldwide based on the number of monthly active users in 2019 (tekno.kompas.com). WhatsApp provides a feature to arrange a group chat for up to 256 people. It allows the group members to have discussions, share files, audio, video, or links, and make a group video call free of charge. It offers the availability of facilitating and learning anytime and anywhere (Gon, 2017) while allowing immediate responses from both teacher and students (Mistar, 2016). These features have made WhatsApp the most used application in Indonesia's online learning process during the global pandemic.

At the National Institute of Technology Malang, the primary platform of e-learning is a web-based Learning Management System (LMS) named SPADA ITN Malang. All the semester's courses include the attendance, materials, links, assignment, file sharing, and course forums, can be accessed online through the web. However, the main disadvantage of a web-based LMS was the lack of two-way communication, which causes the students to understand less about the lecture materials. For Informatics engineering students in the National Institute of Technology Malang, this was the first time they had online learning 
when they enter college. Therefore they faced more troubles in adapting to the system. As a helping tool in coordinating and guiding the students, the English course lecturer initiated to arrange a WhatsApp group for each class in the department. The group was expected to be able to bridge the communication gap between students and the lecturer.

Regarding the use of WhatsApp as an instructional medium, previous research by Gon (2017), Indaryani (2018), Yensy (2020), and Barus (2020) found that both students and teachers have positive perspectives and suggested that the use of WhatsApp is useful in helping the students learning and improving their knowledge (Mistar, 2016). WhatsApp is also proven to be effective in increasing the learning independence of students (Susilowati, 2020) as it offers simplicity, a userfriendly interface, and full features (Shodiq et al., 2020) and able to intensify communication during the learning process (Sari, 2019). Different from these previous studies, this study does not aim to examine the use of WA as the main medium of learning, but concern specifically on the WA Group as a supporting tool for LMS SPADA in student-teacher communication during the online lectures.

The English course in the National Institute of Technology Malang used SPADA ITN Malang and partially used Google Meet for online, face-to-face communication. Therefore, it is essential to investigate the students' perception of using WhatsApp Group as a supporting medium for communication to find the advantages and problems these applications hold. By doing so, the result can be used as development support for the implementation of English course elearning, especially for non-English department students.

\section{Research Method}

This study's research approach is survey research with quantitative research strategies (Ponto, 2015). The population was one hundred students of the first semester in the Informatics Engineering Department in the National Institute of Technology Malang. They enroll in the English Course in the Odd Semester of 2020-2021 academic year from classes $\mathrm{A}$ and $\mathrm{B}$.

In conducting this survey research, the data was collected through online questionnaires using Google Forms. There are 13 questions on the questionnaire. There are three questions requiring descriptive answers and ten questions of a 5-point Likert scale with positive statements. The number given were $1=$ strongly disagree $(\mathrm{SD}), \quad 2=$ disagree (D), $3=$ neutral $(\mathrm{N}), 4=$ agree $(\mathrm{A})$ and $5=$ strongly agree $(\mathrm{SA})$. The higher the number given indicates, the more positive perception. There were five indicators used in filling out the questionnaire: ease of use, usefulness, interaction, advantage, disadvantage, and suggestion. All the information collected was then analysed using descriptive statistics and summarized accordingly to draw the conclusion.

\section{Result and Discussion}

The survey was done by distributing online questionnaires in which 52 complete responses were obtained. 69.2\% (36 students) were male, and $30.8 \%$ (16 students) were female. The results data were compiled, classified into quantitative data and descriptive data, then analysed accordingly.

Questions 1 to 4 (Q1-Q4) covers the ease-of-use aspect of the WA Group. Questions 5 to 8 (Q5-Q8) cover the usefulness aspect, and questions 9 and 10 cover (Q9 and Q10) the communication or interaction aspect. The higher the student's number in every question indicated that the students had a more 
positive perception of the question. The percentage of Q1 to Q10 were displayed in Table 1.

Table 1. Student's Questionnaire Result

\begin{tabular}{|c|c|c|c|c|c|c|}
\hline $\begin{array}{l}\text { SURVEY } \\
\text { QUESTION } \\
\end{array}$ & SD & D & $\mathbf{N}$ & $\mathbf{A}$ & SA & $\begin{array}{c}\text { INTER- } \\
\text { PRETATION }\end{array}$ \\
\hline Q 1 & - & - & $\begin{array}{c}7 \\
(13.5 \%)\end{array}$ & $\begin{array}{c}13 \\
(25 \%)\end{array}$ & $\begin{array}{c}32 \\
(61.5 \%)\end{array}$ & Positive \\
\hline Q 2 & - & - & $\begin{array}{c}2 \\
(3.8 \%)\end{array}$ & $\begin{array}{c}16 \\
(30.8 \%)\end{array}$ & $\begin{array}{c}34 \\
(65.4 \%)\end{array}$ & Positive \\
\hline Q 3 & - & - & $\begin{array}{c}3 \\
(5.8 \%)\end{array}$ & $\begin{array}{c}17 \\
(32.5 \%)\end{array}$ & $\begin{array}{c}32 \\
(61.5 \%)\end{array}$ & Positive \\
\hline Q 4 & - & - & $\begin{array}{c}6 \\
(11.5 \%)\end{array}$ & $\begin{array}{c}15 \\
(28.8 \%)\end{array}$ & $\begin{array}{c}31 \\
(59.6 \%)\end{array}$ & Positive \\
\hline Q 5 & - & - & $\begin{array}{c}8 \\
(15.4 \%)\end{array}$ & $\begin{array}{c}22 \\
(42.3 \%)\end{array}$ & $\begin{array}{c}22 \\
(42.3 \%)\end{array}$ & Positive \\
\hline Q 6 & - & $\begin{array}{c}1 \\
(1.9 \%)\end{array}$ & $\begin{array}{c}13 \\
(25 \%)\end{array}$ & $\begin{array}{c}18 \\
(34.6 \%)\end{array}$ & $\begin{array}{c}20 \\
(38.5 \%)\end{array}$ & Positive \\
\hline Q 7 & - & $\begin{array}{c}3 \\
(5.8 \%)\end{array}$ & $\begin{array}{c}15 \\
(28.8 \%)\end{array}$ & $\begin{array}{c}15 \\
(28.8 \%)\end{array}$ & $\begin{array}{c}19 \\
(36.5 \%)\end{array}$ & Positive \\
\hline Q 8 & - & $\begin{array}{c}1 \\
(1.9 \%)\end{array}$ & $\begin{array}{c}6 \\
(11.5 \%)\end{array}$ & $\begin{array}{c}21 \\
(40.4 \%)\end{array}$ & $\begin{array}{c}24 \\
(46.2 \%)\end{array}$ & Positive \\
\hline Q 9 & - & $\begin{array}{c}1 \\
(1.9 \%)\end{array}$ & $\begin{array}{c}16 \\
(30.8 \%)\end{array}$ & $\begin{array}{c}17 \\
(32.7 \%)\end{array}$ & $\begin{array}{c}18 \\
(34.6 \%)\end{array}$ & Positive \\
\hline Q 10 & - & $\begin{array}{c}1 \\
(1.9 \%)\end{array}$ & $\begin{array}{c}14 \\
(26.9 \%)\end{array}$ & $\begin{array}{c}20 \\
(38.5 \%)\end{array}$ & $\begin{array}{c}17 \\
(32.5 \%)\end{array}$ & Positive \\
\hline
\end{tabular}

Table 1 showed that the students' perception towards three aspects in each survey question was all in high favorable agreement. In terms of ease-of-use aspect, Q1 to Q4 showed a high positive agreement level that no student has disagreed that WA Group was easy to use, easy to access and that every course should have WA Group as well.

In terms of usefulness, Q5 to Q8 showed more various answers. Q5 and Q6 covered the students' convenience while discussing their learning problems in the group and showed positive agreement. Q7 consisted of whether the WA group helped them understand the material delivered by the lecturer on SPADA. While $65.3 \%$ (34 students) had positive agreement, $28.8 \%$ (15 students) remained neutral, and 5.8\% (3 students) revealed that the group did not help them understand the material.
Q9 and Q10 covered the aspect of communication between teacher and students. Positive agreement for both questions was high, but the percentage of neutral answers was also relatively high $(30.0 \%$ and $26.9 \%)$. This number indicated that the lecturer and students' communication was not done optimally and meant that some problems arose during the WA group's use for the communication. The problems that arose could be found in the next descriptive questions.

The results of the descriptive questions (Q11, Q12, and Q13) covered three aspects: advantage, disadvantage, and suggestions, and generated as shown in Table 2. 
Table 2. Student's Descriptive Statements Result

\begin{tabular}{llrr}
\hline \multirow{2}{*}{ ASPECT } & STATEMENT & NUMBER OF & PERCENTAGE \\
\hline Advantage & Ease-to-access & 32 & $61.2 \%$ \\
& Internet Data & 17 & $33 \%$ \\
& Lecturer's Active Participation & 3 & $5.8 \%$ \\
Disadvantage & Spam Messages/Messages Flooding & 40 & $77.2 \%$ \\
& Lecturer's Slow Response & 3 & $5.8 \%$ \\
& No significant problem & 9 & $17 \%$ \\
Suggestion & More active discussion & 50 & $96.2 \%$ \\
& No suggestion & 2 & $3.8 \%$ \\
\hline
\end{tabular}

Table 2 showed that according to the students' statements, the advantage of the WA group aspect covered ease-ofaccess, internet quota, and lecturer's participation. $61.2 \%$ of respondents (32 students) stated that the WA group is easy to operate without any significant hindrance and can be accessed anytime and anywhere in real-time. Thus, it will be easier and faster to check messages to get their learning materials or information from the lecturer. Other 32 students $(17 \%)$ stated that WA used lesser internet data than other messaging applications. This way, they can save money to buy an internet package. During the implementation of e-learning, the students must provide much internet data for all the courses needs, and it was one of the biggest problems in online schools. $3 \%$ of respondents (3 students) stated that the WA group's advantage is that the English lecturer is more active in answering the question or discussing in the group than being chat privately. When there are questions, the lecturer was quick to give responses. As a result, it helped the students gain more information and understanding of SPADA's material.

Regarding the disadvantage, $77.2 \%$ of respondents (40 students) stated that there were too many chats from the group members, so the critical information drowned by other messages. They claimed that other students did not pay more strict attention while sending messages into the group and played with stickers. This made them had to scroll up to find the information given by the lecturer. $5.8 \%$ of respondents ( 3 students) stated that the lecturer was slow to respond that some answers were delayed. However, $17 \%$ of respondents (9 students) claimed that they had no significant problem using the WA group.

Q13 consisted of students' suggestions on the use of the WA group during the learning process. $96.2 \%$ of respondents suggested a more active discussion in the group, such as more question-answer session and share materials followed by direct discussion. The respondents also suggest to turn off the ability to send messages of the group member if the lecturer sends information into the group to avoid unnecessary message flooding. $3.8 \%$ of respondents ( 2 students) stated that they have no other suggestion as to the WA group already helped them enough in the learning process.

\section{Conclusion}

The research findings showed that the Informatics engineering students of the first semester had high positive perceptions toward the English course WA group regarding ease-of-use, usefulness, and communication. The advantages found were ease-of-access, the lesser use of internet data, and the lecturer's active participation in the group. The disadvantage found were spam messages and the lecturer's 
sometimes slow responses. Simultaneously, the respondents suggested that a more active discussion in the WA group will help them gain more understanding of the English materials.

Relevant to the suggestions found, it is the lecturer's responsibility to develop a more optimum communication system using the WA group that can overcome existing learning problems while also increase student motivation and participation as stated by Hamad (2017) that WhatsApp can provide meaningful and contextual interactions, as a solution in teaching communicative competence. However, for the next research, it is necessary to review the use of this WA group from the lecturer's perspective to find issues and challenges that may occur so that lecturers also do not get too much burden during their online lectures.

\section{References}

Amry, A. B. (2014). The Impact of WhatsApp Mobile Social Learning on The Achievement and Attitudes of Female Students Compared With Face to Face Learning In The Classroom. European Scientific Journal, ESJ, 10(22). https://doi.org/10.19044/esj.2014.v $10 \mathrm{n} 22 \mathrm{p} \% \mathrm{p}$

Barus, I. R. G \& Simanjuntak, M. B. (2020). Whatsapp Group and Google Classroom-Based Learning Materials in English Classes: Students' Perceptions. SELTICS Vol. 3 (1), 47-54

Cresswell, J. (2012). Educational Research: Planning, Conducting, and Evaluating Quantitative and Qualitative Research. Ney Jersey: Person Education, Inc.

Susilowati, E. (2020). Bagaimana Pembelajaran Daring di Tengah Wabah Covid 19 melalui Grup WhatsApp? Jurnal Pendidikan
Matematika Raflesia, Vol 05 (3), 125

Gon, S., \& Rawekar, A. (2017). Effectivity of E-Learning through WhatsApp as a Teaching Learning Tool. MVP Journal of Medical Sciences, Vol 4(1), https://doi.org/10.18311/mvp ims.v4i1.8454

Goodwin, et al. (2012). Use of Tablet Technology in The Classroom. State of New South Wales (Australia): The NSW Curriculum and Learning Innovation Centre. Retrieved from www.clic.det.nsw.edu.au

Hani, N. (2020) Indonesia Masuk 3 Besar Pengguna WhatsApp Terbanyak di Dunia, Tapi... Retrieved from https://uzone.id/indonesia-masuk3-besar-pengguna-whatsappterbanyak-di-dunia-tapi-

Indaryani, E., \& Suliworo, D. (2018). Dampak Pemanfaatan WhatsApp dalam Meningkatkan Motivasi Belajar Siswa pada Pelajaran Fisika. Prosiding Seminar Nasional Quantum, 25, 25-31.

Ponto, J. (2015). Understanding and Evaluating Survey Research. Journal of the Advanced Practitioner in Oncology 6(2):16817

Prihatmi, T. N (2018). Pengaruh Media Sosial terhadap Prestasi Belajar Bahasa Inggris pada Program Studi Teknik Mesin ITN Malang. Jurnal Flywheel, 9(1), 18-21. https://doi.org/10.47549/flywheel. v9i1.2555

Sari, F. M \& Putri, S. N (2019). Academic WhatsApp Group: Exploring Students' Experiences in Writing Class. TEKNOSASTIK. Vol 17 (2), 56-65

Mistar, I., \& Embi, M. A. (2016). Students' Perception on the Use of WhatsApp As a Learning Tool in 
ESL Classroom. Journal of Education and Social Sciences, 4, 96-104

Mózo, B. S. (2017). Implementasi Zoom, Google Classroom, dan Whatsapp Group Dalam Mendukung Pembelajaran Daring (Online) Pada Matakuliah Bahasa Inggris Lanjut. Journal of Chemical Information and Modeling, 53(9), 1689-1699. https://doi.org/10.1017/CBO97811 07415324.004

Wahyunanda, K.P. (2020). WhatsApp Tembus 2 Miliar Pengguna. Retrieved from https://tekno.kompas.com/read/202 0/02/13/18190017/whatsapptembus-2-miliar-pengguna

Wijaya, A. (2018). Students' Responses Toward the Use of Whatsapp In Learning. Journal of Teaching \& Learning English in Multicultural Contexts, Vol 5 (1), 46-55

Yensy, N. A. (2020). Efektifitas Pembelajaran Statistika Matematika melalui Media Whatsapp Group Ditinjau dari Hasil Belajar Mahasiswa (Masa Pandemik Covid 19). Jurnal Pendidikan Matematika Raflesia, Vol 05 (2), 65-74 